HISTORIA: Jurnal Pendidik dan Peneliti Sejarah, 3(2), 93-102, DOI: https://doi.org/10.17509/historia.v3i2.23836.

Available online at HISTORIA; Jurnal Pendidik dan Peneliti Sejarah
Journal homepage: https://ejournal.upi.edu/index.php/historia

\title{
HERITAGE OF THE PAST: ADDRESSING PHILIPPINES ECOLOGICAL FOOTPRINT AND LOCAL WISDOM THROUGH COPRA-MAKING PRACTICE
}

\author{
Roel V. Avila \\ The National Center for Teacher Education, \\ Philippine Normal University, Manila, Philippine \\ avila.rv@pnu.edu.ph
}

To cite this article: Avila, R.V. (2020). Heritage of the past: addressing Philippines ecological footprint and local wisdom through copra-making practice. HISTORIA: Jurnal Pendidik dan Peneliti Sejarah, 3(2), 93-102. https://doi.org/10.17509/ historia.v3i2.23836

Naskah diterima : 21 Februari 2020, Naskah direvisi : 11 Mei 2020, Naskah disetujui : 14 Juni 2020

\section{Abstract}

This article emerged from the author's apprehension regarding the lack of social sensitivity caused by the failure to connect the environment to the school lessons. Furthermore, creating balance and harmony within society and environment seemed impossible to realize in this sense. As in the Philippines in this case, schools often negated the significance to connect the environment to schools. From author point of view, the fact that the Philippines has strong ecological footprints and the local wisdom which can be traced through copra-making industry should not be discharged. The author examined this ecological intelligence which manifested inherently among the kinfolk of copra-makers by elaborating the indigenous cultural practices of the rural folks in the Philippines and making sense of those practices with metaphorization to advocate and conduct more connection in the classroom. As a result the highlighted indigenous processes that provided as a model in contextualizing sociological, cultural, and historical accounts as an ethno-pedagogical strategy of integrating nationalism in social sciences teaching.
\end{abstract}

Keyword: Copra-making process; ethno-pedagogy; local wisdow; nationalism; Philippines indigenous cultural practices. 


\section{INTRODUCTION}

The prevailing lack of social sensitivity can be attributed to the failure to connect the environment to the school lessons. This problem consequently pushes for the improvement of ecological intelligence among the social studies learners (Septiarini, 2016) who culturally go astray. And for several years, only few could trace the ecological footprint and the local wisdom embedded in the century-old indigenous industries such as copramaking. Such ecological intelligence is inherent among the kinsfolks of copra-makers but schools hitherto have failed to strongly connect the environment to the schools. To decolonize is to create balance and harmony within ourselves and our environment (Torres, 2007). In consequence, the current educational system produces a society with less awareness on civic republicanism with focus on shared autonomy of the community, but more autonomy-producing individuals (Vontz, 2000). Moreover, in order to assuage the effects of modernization to the citizens (alienation psychologically and spatially from the land), there has to be new paradigms that are necessarily ecologically-based and ethnically-based (Supriatna, 2016) which can potentially restore the essence of humanity as humans living in harmony with nature in accordance with the concept of sustainability (Gadoti, 2010). School instructions ought to be seen through ethno-pedagogical eyes to wield individuals to the society and to the environment which form parts of ecological niche.

Ethnically, I am the tenth offspring of a Tagalog coconut farmer and a Tagalog-Bicolano housekeeper. Although my father owned a five-hectare coconut farm, my parents found it hard to keep both ends meet. At the age of 5, I was not yet aware of how our family was affected by the fluctuation of the prices of copra both in the local and the international markets. What I knew was the benefits we could get from our coconut trees (cocos nucifera). The swaying of coconut leaves or the damage the insects did to them gave me the omen for the coming storm or the decrease in the quantity and quality of harvest.

Just like every Filipino child, I was afraid of typhoons because of the strong wind and the danger it posed to our habitation which was made from coconut lumber and coconut leaves. I used to hear my nanay (mother), a housekeeper, telling my tatay (father) after the visit of each typhoon how our family could recover from the losses: some fallen coconut trees, the levelled-to-the-ground banana trees, the damaged rice crop, and the effects to the coconut fruits. My father used to say that it takes a whole year before a young coconut becomes a mature one to be ready for copra-making, the experienced-based wisdom which found concurrence from scholars (Maier, 2019). Thanks to the tap roots: the camote (ipomoea batatas) and balinghoy (manihot esculenta crantz) which provided as our staple food during the post-typhoon days. And most importantly, thanks to my parents for their resiliency against the natural calamities that our family experienced. Such resiliency was characterized by their creativity and local wisdom. Resiliency is a resounding common value among Filipinos. There is just the need for the exploration of local wisdom of ethnic groups in order to safeguard the people from the environmental damage caused by anthropocentrism (Supriatna, 2017) and globalization (Sabiq, 2017).

I witnessed how my parents and the people in our barangay (village) made use of their local wisdom such as engaging in pasaknong or bayanihan (extending a helping hand to fellow villagers for free), the use of carabao horn in calling village folks for an important assembly, the use of simple machines and traps to facilitate farm works and hunting for wild animals, and the skills in weaving coconut palms to serve as roofs and walls of bahay-kubo (hut). Among the many farm tasks, the copra-making gave me the most exciting and interesting experiences. When I was aged 10 years old, I was walking under the coconut trees and a swishing sound prompted me to run. Because of too much familiarity with the sound, I knew it was a young coconut falling from its tree. To look up to the source of sound would have been fatal because my face would surely be hit. That's the impact of coconuts to me. If it threatened my life at the early age of 10 , now that I am aged half-a-century, I know that I can still learn much from studying it as to its many benefits being called a tree of life and some threats such as coconut leaf beetle infestation (gmanetwork.com., 2007).

As a five-year-old kid, I could count in my fingers the copra-making processes in the correct order: paghahawan (farm cleaning), pangangawit (dislodging), pag-iipon (gathering), paghihila (hauling), pagbubunot (dehusking), pagbibiyak (splitting), pagsasalang (piling), pagtatapa (heating), pagtitigkal (splitting), pagsisilid (bagging), pagtitimbang (weighing), and pagbebenta (selling). I never had any hint that I would become a teacher someday and that these 12 major processes can be of great help for me in dealing with ethno-pedagogy. My appreciation to the national heroes, nationalistic teachers, patriotic movies and songs, and other experiences that guided me to go back home.

It is my turn to help the copra-makers' kinsfolks find their way home. In this article, I will exemplify how local copra-making processes can serve as model 
HISTORIA: Jurnal Pendidik dan Peneliti Sejarah, 3(2), 93-102, DOI: https://doi.org/10.17509/historia.v3i2.23836.

in contextualizing sociological, cultural, and historical accounts as an ethno-pedagogical strategy of integrating nationalism in the teaching of social sciences. Sideheadings in this article represent the said indigenous processes as pegs in linking classrooms and communities through place and community-based education (Serafico, 2017; PNU, 2018). At the end of each subtopic is a sentence (in italics) which contains both the pedagogical and nationalistic themes derived from each process through metaphorization.

As a young branch of scientific-pedagogical knowledge, ethno-pedagogy paradigm involves an awareness and appreciation of cultural wisdom for national identity (Klara, et al., 2013). Copra-making has been imbedded in the cultural practices of the rural folks in the Philippines, being the second leading exporter of copra in the world market (trendingtopmost. com., 2017). Philippine Coconut Authority reported that around 3.517 million hectares in the Philippines are coconut farms which is $26 \%$ of the total agricultural land; 68 out of 81 provinces (leading is Quezon Province where I grew up) are planted to coconut trees (pca.da., 2015).

The best places to teach nationalism are the school and the home. The children of coconut farmers are exposed to both copra-making processes at home and socialization processes in the school. So, copra-making is completely known among the select learners and this can be taught using metaphorization (Klara, et al., 2013; Lin Ma \& Aihua Liu, 2008; Croft \& Cruse, 2004; Kovecses, 2002) through ethno-pedagogy (Kartadinata, et al., 2015).

\section{Paghahawan (Farm Cleaning)}

Farm cleaning (Paghahawan) is the removal of stumps, plants, or anything that blocks the paths of the copra farmer, the carabao, and the cart. It is not sound to start actual copra-making without cleaning the farm first. All things, such as stumps, twigs, vines, fallen logs, and thorns, are removed to expedite the activity. One day, when I was engaged in hauling, my kangga (cart) bumped into a stump. The carabao, due to inactivity, became impatient, disentangled from its cart, and rushed to the brook. I got my bolo and cut the stump for my cart to pass through. That incident gave me the idea on the importance of farm cleaning.

A stump symbolizes colonial mentality. Colonial mentality is the thought that foreign talents and products are always the best, and that the local ones are of poor quality (Royeca, 2010), a form of internalized oppression (David \& Okazaki, 2006), and involves an unreasonable rejection of anything Filipino and uncritical preference for anything foreign brought about by more than four centuries of colonization (Gabornes, 2010). This menace permeates into almost all facets of Filipino society. It is considered inimical to cultural, social, and economic advancements. There has to be a decolonization particularly in the field of teaching (Avila, 2016).

Teaching is not outright started should there be colonization-related cultural practices (Alvares, \& Faruqi, 2012). These impediments should have been removed but due to the neo-colonial education since the American colonization, it has continued to sow and grow unnecessary yet detrimental weeds (Gabornes, 2010) in the country. Instead of teaching nationalism, some teachers disown their patrimony by encouraging the farmers' offspring to leave their farm and reside in the urban areas. The young Filipinos eventually express negative attitude toward farming. Instead of taking up agriculture-related courses in order to attain industrialization, they shift to jobs that require them to flock to the urban areas. Since farmers are the poorest and hungriest in the Philippines, the young Filipinos refuse to go into farming (Geronimo, 2014). This practice is the microcosm of the Philippines' economic malpractice. Instead of focusing on improving the agricultural industry (De la Cruz, 2017), the country wants immediate take off toward commerce.

Before a teacher starts the lesson, there must be cultural expurgation first in order to help the kids retrace the paths their ancestors traversed. The important pedagogical idea is: Do not begin when the field is not yet ready. A ready learner is a decolonized learner.

\section{Pangangawit (Dislodging)}

Dislodging is the second process in copra-making wherein the copra-maker uses bamboo poles with a metallic blade attached to its end in order to dislodge the coconuts from their stems. I knew how to dislodge fruits from the short coconut trees. However, I have not yet tried dislodging coconuts from at least a 20 -foot tree. It is very difficult. It requires skills and foresight. Keen vision is needed to identify both the brown mature coconuts and the shakers from the rubber meat coconuts and the spoon meat coconuts. An experienced 'dislodger' knows how to easily distinguish them. Brown mature coconuts are aged 12 to 14 months old. They weigh lighter than the shakers because a mature coconut's husk begins to dry as its shell gets harder. Shakers still have the skin colors. Brown coconuts and shakers are the ones dislodged. There are many varieties of coconuts - 14 varieties 
according to floridagardener.com (2015) - but I want to focus on the varieties of Malay coconuts. They are Golden Malay, Green Malay, and Yellow Malay coconuts. Whatever the color is, all mature coconuts turn into brown - figuratively pointing to the brown-skinned Malays. Some workers climb the trees using notches cut into the trunk (Obsidian Soul, 2011), instead of using bamboo poles. I climbed coconut trees more than twenty times. Coconut climbers have the better vista than the coconut dislodgers on the positions and structure of coconuts above.

Similarly, a classroom teacher has the more feasible and specific teaching-learning plan than the educational planners. Since the teacher plans the lessons, the endgoals of education must be clear in both the teachers' and the students' minds. Dislodging connotes planning on how to reach the goals. Reaching the goals require dispositions. To produce nationalistic citizens, teaching has to be anchored on the Four Pillars of Education, 21st Century Skills, National Council for Social Studies standards, National Motto, Goals of Social Studies/ Science, and the $\mathrm{K}$ to 12 Learning Competencies. The learners must be made aware of such goals (Acero, et al., 2007). The goals, methods, and evaluation must be congruent with one another (Mellon, 2013). The teachers are the first to know all these (Avila, 2017; Gregory, 2014).

Personal plans which concern professional and financial goals have to be in conformity with the national plans and its thrust (NEDA, 2018). Learners must be guided on how to learn from the process of personal renewal before they advocate for social transformation (PNU Philosophy). The harder the lesson, the more perseverance is needed. Simple lessons, however, need little studying as short coconut trees need few pieces of bamboos for dislodging. Their advocacies remain as active learners first, then as active citizens afterwards. Their advocacies resemble a compass that points to the right direction towards their ancestral home.

Both the teachers and the learners set goals and standards. Individual citizens must connect their personal plans to national plans.

\section{Gathering (Pag-iipon)}

Dislodged coconuts fall to the ground. Some coconuts fall and stay together as a bunch while some are detached from the bunch and roll away. This is one of the reasons why coconut farm cleaning is necessary. Coconuts that roll towards the thickets are hard to find and gather. Since I did not engage in dislodging coconuts, my frequent role was on being a gatherer. I had to wear thick jackets, jeans, and a pair of rubber boots. My gathering stick had to be as tall as I was in order to reach coconuts that rolled towards the thickets.

Gathering may metaphorically pertain to the 2.2 million overseas Filipino workers during the period April to September 2016 (PSA. 2017). OFWs, Despite of their all-time-high remittances, $\$ 26.93$ billion in 2014 (Rodis, 2015), the Filipino diaspora (Jewish term for the scattering of people abroad) is quite alarming since about 14 million Filipinos are in diaspora as of now. The OFWs, called modern-day heroes and saviors of the economy by 2003 Supreme Court decision, have to be gathered a-la Zionism and assured of stable jobs in their country.

Scattered Filipinos abroad have left culturally confused offspring back home. When the students' attention is fragmented, learning seldom occurs. Learners must gather their senses and focus them on the lesson. Their experiences in both formal and informal education can be used in the analysis of the ideas. Getting and maintaining the learners' attention is a must in learning (Gregory, 2014; Mursel, 1946). These children of coconut farmers must gather their senses and focus on their decolonized lessons. Like the OFWs, these children must tread on the footpath their ancestor did.

Learners have to gather their senses and focus. It is about time for the OFWs to engage in Filipino Zionism.

\section{Paghihila (Hauling)}

Most farmers use a cart pulled by a carabao. The farmer holds the rein and controls where the beast should go. The paths depend on the small piles made during the gathering. All these paths lead to the work area. For me, hauling is the most exciting process due to the man-animal-plant interactions. I set the carabao to pull a cart where I rode. While pulling the cart, my carabao would stick out its tongue to get the blades of grass and cut them with its teeth. It swallowed its food quickly, with only minimal mastication. When the cart is put to a halt for a while, it would regurgitate the partially chewed food, re-chew it, and then swallow it again in the process known as rumination (Lofgreen et al., 1957). I was not yet aware of the process of rumination before. I just used to see my carabao chewing the cud while resting. It gave me the idea that as a student, I should get as much bits of information as I could from the environment then engage in my own 'rumination' by pondering on those ideas when I reached our house. This made me conscious of my environment. 
HISTORIA: Jurnal Pendidik dan Peneliti Sejarah, 3(2), 93-102, DOI: https://doi.org/10.17509/historia.v3i2.23836.

Filipino consciousness enables Filipinos to love their country which is succeeded by service to the country (Villar, 2017) for love propels service. Love pulls service as the carabao pulls the cart. The government needs a comprehensive plan on elevating the nationalistic ideals of the Filipinos through the Department of Culture: Senate Bill No. SBN-1528: AN ACT ESTABLISHING THE DEPARTMENT OF CULTURE, APPROPRIATING FUNDS THEREFOR, AND FOR OTHER PURPOSES.

Since teaching is a complex process, the teachers must be motivated by their desire (or love) to serve the learners. There are many paths to learning (Tiberius \& Tipping, 1990), though knowing the unknown through what is known (apperception) still rules those paths (Gregory, 2014). In order to facilitate the hauling of learners towards better education, the teachers must hold the rein. The teachers must lead these offspring of the coconut farmers to know the cultural significance of their parents' occupation for better appreciation of their families' contribution to national economic growth.

The young generation must experience the many ways to learning before extending their services to the country.

\section{Pagbubunot (Dehusking)}

Dehusking is the removal of the husk from the coconut through the use of a wooden tripod with a triangular metal on its tip. I could dehusk coconuts but not as fast as a skilled dehusker could do it. The process of dehusking uncovers the real coconut inside. Whenever I tried to dehusk coconuts, I was always excited to find out the uniqueness of each coconut that the husk and its skin's color used to hide.

Filipinos' real Malay identity is enveloped by their Western-inspired cultural practices. In order to expose such real identity, the husk must be torn and removed. This is symbolic of the process of re-indigenization. Filipinos who are conscious of the present specific cultural practices, recognize that they are meaningful due to their nexus in the past and how they affect themselves in the future. Connecting the present to the past necessitates a re-indigenization (Sta.Maria, 1996) which needs to overcome local neocolonial formation (San Juan, 2006), and the conduct of research using the emic instead of the etic point of view (Sta. Maria, 1996; Enriquez, 1992). Dehusking figuratively means indigenization. This article of mine uses the emic point of view.

Learning is meaningful (Tiberius \& Tipping, 1990) because of the interconnection among the past, the present, and the future. It will be impossible not to focus on nationalism in the process. When the learners connect the new lesson to their life, the teacher has attained her goals (Serrano \& Paez, 2015). It is the learners themselves who discover the significance of the lesson (Gregory, 2014) and in this process of knowing what is unknown through what is known is setting the trajectory learning to what the children of coconut farmers want to know (Campbell \& Campbell, 2009).

Learning is made more meaningful if there is reindigenization.

\section{Pagbibiyak (Splitting)}

From being one, the coconut will be split into two halves using a sharp bolo. Coconut farmers call the half with two 'eyes' and a 'mouth' as male and the other half with three lines under it as female. My splitting skills reached its peak when I used to strike each coconut only once. The sound of broken shell and the splash of coconut water seemed like music to my ear.

If dehusking is the removal of Western influences from the Malayan culture, splitting is the act of exposing the preference to Western culture by these brown-raced Filipinos. This West-East-West Filipino cultural identity is best typified by the husk-shell-meat structure of the coconut fruit (Yellow husk, brown shell, and white meat). In other words, the Malay identity of each Filipino is sandwiched by Western influences. They want to look white (West) but they look brown (East) and so they behave like white (West) through acculturation. And it takes 'dehusking' and 'splitting' to tell these Filipinos that they have culturally gone astray.

They were once one and now they are split. In the pile of coconut shells, they can still find each other. An astray Filipino can still find his way home. This line also refers to the meeting of man and woman. Splitting symbolizes the family. From the ancient myth, man and woman were one inside a bamboo and when a bird picked and divided it, came the first man (Malakas or Strong) and first woman (Maganda or Beautiful). Family commences with the re-union of man and woman. They overvalue family life, making Filipinos as clannish as ever. Whatever happens, the family is the last resort, though socio-political issues in the country have affected family cohesiveness (Tarroja, 2010). Splitting highlights the distinct roles of husband and wife, a sort of specialization and division of labor. In the national level, specialization and the division of labor are the most important causes of economic progress (Adam Smith, 1776). A husband and a wife are specialists in their own roles and their synergy spells family success.

Various tasks assigned to learners are done for common goal (De Ocampo-Acero, Sanchez-Javier, \& 
Ocampo-Castro, 2015), and the product of working together improves while their level of understanding gets high (Horne \& Pine, 1990). Learners are trained to be specialists and they are encouraged to collaborate with one another. Being together in their journey makes the search for the old path easier.

Learners are encouraged to collaborate with one another. Division of labor and unity in purpose relive the essence of bayanihan.

\section{Pagsasalang (Piling)}

Piling is the process of arranging the split coconuts on the bamboo heating floor. It takes time for a copramaker to do it and some of them display wisdom and creativity to ensure that all pieces would be exposed to enough heat. My father taught me how to pile the split coconuts which formed a regular geometrical arrangement over the heating floor. The object is to pile the split coconuts where the heat and smoke of the oven can permeate evenly into the pile. The pile is highest at the center because the central part of the heating floor receives the greatest amount of heat from the oven below. The act of piling each half of split coconut is a metaphor of an advocacy. Advocacies start at home and school. Children who are used to being involved in various advocacies would make active citizens (De OcampoAcero, 2015; Concepcion, 2014). No matter how insignificant each advocacy seems, the combination of all these make a difference.

Teaching is good if the learners are motivated to think and reason out (Acero, et al., 2007). Learning starts with the moment the teacher gives the learners the opportunity to express their thoughts and views (De Ocampo-Acero, 2015). Active involvement of the learners facilitates learning (Tiberius \& Tipping, 2015). Studying well is the children's contribution to their country. They have to avoid vices and evil peers and to do what is good under the protection and guidance of the family. These children of coconut farmers shall involve themselves in finding their way back home - to the indigenous culture that their ancestors had.

Students who engaged in experiential learning can contribute significant advocacies beneficial to their families and country.

\section{Pagtatapa (Heating)}

Heating is a copra-making process where the piled pieces of coconut are heated under the bamboo heating floor using an earthen oven whose fuel are the husks. This process is crucial because it requires responsibility.
Irresponsible copra-makers could endanger the efforts exerted in the preceding processes. The heat produced by the burning of husks in an earthen oven should be neither too low nor too high. This act of regulating the heat is attained by the combination of dry husks (from mature coconuts) and fresh husks (from a shaker coconut). The sluggish but wise old folks if combined with active but inexperienced youth is a good combination in regulating nationalistic advocacies.

All citizens must be under heat to sustain their vitality. Active involvement is always preferable than being passive recipients of other persons' ideas. They that do not build, destroy the society. Active citizenship can change the country for the better (Nosko \& Szeger, 2013). Their continuous activity must be regulated. Too much heat could mean too much criticism and too much bashing. Lack of criticism may resemble pouring cold water instead of adding fuel to the fire. The aim should be the utilization of a friendly fire (producing well-cooked copra) that leads to neither a choking thick smoke (producing half-cooked copra) nor a conflagration (producing an overcooked copra) which are both inimical to the society.

Heating figuratively causes the learners to interact, to freely express their thoughts and stand on certain issues (Gregory, 2014; Acero, et al., 2007). Social interaction brings awareness to one's condition in and contribution to the society where they belong.

The heat of interaction produces strong and resilient learners and citizens.

\section{Pagtitigkal (Scooping)}

Scooping is the ninth process in copra-making where the coconut meat which passed the heating process would be detached from its shell using a scooping instrument. Due to the use of sharp metallic instrument, the copra-maker is in danger of wounding himself. He wears a glove in his hand to protect himself. Halfcooked copra makes scooping quite tough, thus, it must be re-heated. Half-cooked copra is prone to 'aflatoxins' a poisonous microbe which, when taken by horses or cattle, attacks and weakens the beasts' respiratory system (Kumar, Mahato, Kamle, Mohanta, \& Pradeep, 2016). Copra-makers like me dislike uncooked copra. Besides the difficulty we experience in detaching the meat from the shell, it puts the copra-maker to danger. On the other hand, there are well-heated split coconuts that can be easily detached from their shells.

Experiencing independence creates a ripple effect from the self to the family, to the community, and to their country. Independence differs from freedom. Citizens 
HISTORIA: Jurnal Pendidik dan Peneliti Sejarah, 3(2), 93-102, DOI: https://doi.org/10.17509/historia.v3i2.23836.

who vehemently criticize yet do not offer solutions to societal problems resemble the 'aflatoxins'. They bash their fellows without studying all angles, hence halfcooked. Aflatoxins are poisonous. The country needs builders, not destroyers of the Filipino identity.

The act of the learners who are motivated to think and express themselves (Acero, et al., 2007) is tantamount to instructing them to get out of their teachers' shadow. The learners benefit from taking responsibility in the acquisition of their own learning (Tiberius \& Tipping, 1990). Finding an old path by their own initiative and doing brings joy and excitement to kids who desire to reach their ancestral home. Experiencing self-sufficiency creates a ripple effect from the self to the family, to the community, and to their country (Taylor, 2013).

Filipino self-esteem is quite fragile, unless it is underpinned by self-sufficiency.

\section{Pagsisilid (Bagging)}

The pieces of copra are placed inside the sack and a long pestle (taller than a man) is used to make the copra dense to accommodate more inside the sack. Both the weight of a sack of copra and its price could be estimated through the size of each sack and how dense the copra is. There are sacks made especially for copra although farmers can also use the sacks used to contain milled rice. The sack's 'mouth' is closed by buri leaves or buntal (rope made from buri palm's stalk). The sacks of copra are placed on a cart pulled by a carabao toward the copra buyer's place.

The learners have to be open-minded due to many conflicting ideas. After hearing all available ideas, they must decide which ones they want to adopt. Bagging is the application of learning. After gathering the needed knowledge and skills, the learners are guided how to apply such knowledge and skills to solve their own problems first and the social problems later (Acero, et al., 2007), leading to the betterment of their socio-economic conditions. The more pieces of advice as to what they need in their journey, the easier the learners can connect paths toward finding their lost identity.

Application of learning contributes to the improvement of national economy and patrimony.

\section{Pagtitimbang (Weighing)}

Weighing is determining the weight in kilograms of the sacks of copra and computing the equivalent amount of money. Official weighing is done in the presence of the copra-maker and the copra buyer. A false weighing scale invites strife and it is exploitation of the poor and the powerless. We used to call a list of the weighed sacks of copra and their corresponding weights and prices as pisada.

Critical thinking has its importance that citizens must know (Regan, 2015) in order to extricate from the web of bashing and negative criticisms. Citizens need to distinguish the difference between constructive and destructive criticisms. They should know how to give credit to government leaders when recognition is due.

Weighing is determining the strengths and weaknesses of the learners (Serrano \& Paez, 2015). Critiquing helps the learners understand what else they can do in order to improve their performance. Teaching is good if evaluation is made a salient part of the teaching process because evaluation measures the effectiveness of teaching and the degree of learning because teaching is valuable only if the objectives are met (Acero, et al., 2007). Constant exposure to evaluations aids the learners to hone their problem-solving skills and their capability to treat successes and failures as students and citizens. The ultimate determinant of the learners' success is their capability to connect the present to the past. In the words of Walker (1983), "If the present looks like the past, what does the future look like?"

Critical thinking makes the learners and the citizens evaluation-ready.

\section{Pagbebenta (Selling)}

Selling is the last process in copra-making wherein the weighed sacks of copra are given corresponding amount of money based on the existing price in the community. Some copra buyers lend their sacks to the copra-makers. In this way, they are assured of having regular customers. When bagging was about to start, we used to go to the copra-buyer to ask for empty sacks. For copra-makers who run out of budget for their food while processing the copra (like us many years back), we requested for a loan in the form of money or groceries. Some copra-buyers own grocery stores. In a capitalistic set up, middlemen like copra-dealers earn much more than what the copra- makers earn. The latter have richer experiences, anyway, by being with nature.

Knowledgeable, skilled, and talented citizens contribute to the clear definition and heightening of national identity. The Philippines is a product of colonialism. Colonization made the Philippines, and it is thus a part of their real identity (Sta. Ana, 2013). They can rid themselves of inferiority. Superiority can be acquired through proper education. When the local is highlighted and valued, the Filipino culture can merge 
with the world's dominant cultural patterns. It is neither global nor local, but glocal image!

The combination of time and talent produces learning (Tiberius \& Tipping, 1990). Knowledge and skills can only be attained by solely giving sufficient time and energy in order to enrich the talents (Serrano \& Paez, 2015). The product of conscientious learning is finding the way home - the re-discovery of the young generation's national identity. Coconuts vary in color but when they mature, the color becomes brown. In this stage, the brown color of the shell matches the brown color of the skin and its husk (coconutinformation.com., 2019). And processes of maturation culminates into the detection of Malay identity.

Enriching time and talent are important factors that lead to the uncovering of national identity.

\section{CONCLUTION}

The 12 processes of copra-making overflow with ideas which are rich sources of metaphorization. The said ideas can metaphorically apply to pedagogy and nationalism wherein the 12 copra-making processes can serve as pegs for both pedagogical and nationalistic themes. These pegs taken from the copra-making processes connect the present to the past, the current to the indigenous cultural practices, hence helping the present generation, especially the offspring of the coconut farmers find their way back home. The young generation of learners, through the resiliency shown by their ancestors, can bravely face the storms and return home. Their old home consists of the pre-colonial culture, the Malayan culture that needs to be studied for the purpose of highlighting the young Filipinos' national identity. And as my social science students learn from me as their teacher, I also learn from my parents and from our common ancestors. The words of Milner (2011) significantly highlight the symbolic relationship between the early Malays and the coconut trees, "Malay of yesteryears believed that the coconut trees were joyful upon hearing the noise of those who resided near the coconut trees." Coconut trees, then, enhance Malay identity. To further develop the ethno-pedagogy paradigm and practice, lesson study approaches may be used by the mentors with incorporation into assessment activities (Kartadinata, et al., 2015). So, being the Technology and Livelihood Education Hub, the Philippine Normal University - Luzon Selatan may encourage the faculty and preservice teachers to integrate ethno-pedagogy in lesson preparations and in its internship program. In this way, preservice teachers, the kinfolk of copra-makers, can return home themselves and instruct their future learners to do the same. Thanks to ethno-pedagogy.

\section{REFERENCES}

Acero, V., Javier, E., \& Castro, H. (2007). Principles of teaching 1. Quezon City: Rex Book Store, Inc.

Alvares, C., \& Faruqi, S. S. (Eds.). (2012). Preface to decolonizing the university. Penang, Malaysia: Penerbit Universiti Saine Malaysia.

Avila. R. P. (2017). Pedagogical Repertoire for Developing Civic Competence in the Elementary Social Studies Curriculum: A Perspective from Philippines. A Paper Presented at The 2nd Asian Education Symposium, December 6, 2017, at Lombok Raya Hotel, Lombok Mataram, Nusa Tenggara Barat, Indonesia

Avila, R. V. (2016). Decolonizing filipino colonial mentality. In N. Supriatna, B. Hetharion, M. Tapung, S. Bahri, \& Rusmawan (Eds.). Promoting Justice and equal world, 1. Universitas Pendidikan Indonesia, Bandung, West Java, Indonesia.

Campbell, L., \& Campbell, B. (2009). Mindful learning: 101 proven strategies and teacher success. California: Thousand Oaks.

Coconutinformation.com (2019). Coconuts vary in flavor \& use depending on their age. Retrieved February 5, 2019 from https://www.coconutinformation.com/ cocos

Concepcion, J. (2014). Young heroes and their advocacies. Retrieved June 16, 2018 from https://www.philstar. com/business/2014/08/14/1357233/young-heroesand-their-advocacies

Croft, W., \& Cruse, D. A. (2004). Cognitive linguistics. Cambridge: Cambridge University Press.

David, E. \& Okazaki, S. (2006). The colonial mentality project. In Gabornes, M. C. (Ed.). Colonial mentality: a filipino heritage? Retrieved September 12, 2016 from http://learningfragments.blogspot.com

De Ocampo-Acero, V., Sanchez-Javier, E., \& OcampoCastro, H. (2015). Principles of teaching I. Manila: Rex Book Store.

De la Cruz, J. (2017). DA told: Focus on agriculture production to alleviate poverty. Retrieved February 4, 2019 from https://businessmirror. com.ph/2017/01/30/da-told-focus-agricultureproduction-alleviate-poverty/

Enriquez, V. G. (1992). From colonial to liberation psychology: The Philippine Experience. Quezon City: University of the Philippines Press. 
HISTORIA: Jurnal Pendidik dan Peneliti Sejarah, 3(2), 93-102, DOI: https://doi.org/10.17509/historia.v3i2.23836.

Floridagardener, (2015). Coconut palms. Retrieved February 5, 2019 from http://www.floridagardener. com/palms/coconutpalm.htm

Gabornes, M. C. (2010, March 11). Colonial mentality: A filipino heritage? Retrieved from http:// learningfragments.blogspot.com

Gadoti, M. (2010). Reorienting education practice towards sustainability. Journal of Education for Sustainability, 4, 203.

Geronimo, J. (2014). Inclusive growth must start with agriculture. Retrieved February 4, 2019 from https:// www.rappler.com/business/economy-watch/66204agriculture-inclusive-growth

Gmanetwork.com. (2007). Report: 26 provinces quarantined for coconut pest. Retrieved February 5, 2019 from https://www.gmanetwork.com/ news/news/regions/62343/report-26-provincesquarantined-for-coconut-pest/story/

Gregory, J. M. (2014). The seven laws of teaching. Moscow: Cannon Press.

Horne, \& Pine (1990). In Corpuz, B. \& Salandanan, G. (2003). Principles and strategies of teaching. Manila: Lorimar Publishing, Inc.

Kartadinata, S., Mamat., Malhiah, E., \& Pheeney, C. (2015). Investigating the impact of 'UPI Cultural Market 2015' in developing ethno-pedagogic paradigms. Research on ethno-pedagogy strategies and tools. Universitas Pendidikan Indonesia, Bandung, West Java, Indonesia.

Klara, K. (2013). Ethnic pedagogy as an integrative, developing branch of pedagogy. Mediterranean Journal of Social Sciences, 6(1), 612-613.

Kovecses, Z. (2002). Metaphor: A practical introduction. New York: Oxford University Press.

Kumar, P., Mahato, D., Kamle, M., Mohanta, T., \& Pradeep, S. (2016). Aflatoxins: A global concern for food safety, human health and their management. Front Microbiol, 7, 2170. doi: 10.3389/fmicb.2016.02170

Lin Ma, \& Aihua Liu (2008). A universal approach to metaphors. Intercultural Communication Studies, 27(1), 260-268.

Lofgreen G., Meyer J., \& Hull J. (1957). Behavior patterns of sheep and cattle being fed pasture or soilage. Journal of Animal Science, 16, 773-780.

Maier, C. (2019). How long until a coconut tree matures? Retrieved February 4, 2019 from http://homeguides. sfgate.com/long-until-coconut-tree-matures-87963. html

Milner, A. (2011). The malays. United Kingdom: John Wiley \& Sons.
Nosko, A., \& Szeger, K. (2013). Active citizenship can change your country for the better. Retrieved June 16, 2018 from https://www.opensocietyfoundations. org/ voices/active-citizenship-can-change-yourcountry-better

Mellon (2013). In De Ocampo-Acero, V., SanchezJavier, E., \& Ocampo-Castro, H. (2015). Principles of teaching I. Manila: Rex Book Store.

Mursel (1946). In De Ocampo-Acero, V., SanchezJavier, E., \& Ocampo-Castro, H. (2015). Principles of teaching I. Manila: Rex Book Store.

NEDA or National Economic Development Authority. (2018). NEDA-DBM-DOF joint statement on the May 2018 inflation report. Retrieved June 18, 2018 from http://www.neda.gov.ph/2018/06/05/ neda-dbm-dof-joint-statement-on-the-may-2018inflation-report/

Nosko, A., \& Szeger, K. (2013). Active citizenship can change your country for the better. Retrieved June 16, 2018 from https://www.opensocietyfoundations. org/ voices/active-citizenship-can-change-yourcountry-better

Obsidian Soul. (2011). Notches cut into the coconut trunk to facilitate easier climbing and harvesting, Philippines. Retrieved February 5, 2019 from https:// www.growables.org/information/TropicalFruit/ Coconut.htmikimedia.org.

PCA or Philippine Coconut Authority (2015). Coco Statistics - Philippine Coconut Authority. Retrieved, 1 January 2018, from pca.da.gov.ph > Industry.

PNU - Philippine Normal University. (2018). Handbook for PNU Students. Manila: PNU Press.

PSA. (2017). Total number of OFWs estimated at 2.2 million (Results from the 2016 Survey on Overseas Filipinos). Retrieved June 13, 2018 from https://psa. gov.ph/content/total-number-ofws-estimated-22million-results-2016-survey-overseas-filipinos

Regan, K. (2015). Six benefits of critical thinking. Retrieved June 17, 2018 from https://learn.filtered. com/blog/6-benefits-of-critical-thinking

Rodis, R. (2015). Vision and action for the Filipino diaspora. Retrieved June 13, 2018 from http://www. cfo.gov.ph/news/cfo-news-and-events/3372-visionand-action-for-the-filipino-diaspora-2.html

Royeca, J. E. (2010). Colonial mentality. Retrieved, 28 July 2016, from http://emanila.com/philippines/ colonial-mentality/

Sabiq, I. (2017). Local wisdom - based spatial management for constructing ecoliteracy in social studies learning. Empowering and Engaging 21st 
Century Learner through Social Studies Education, 2. Universitas Pendidikan Indonesia, Bandung, West Java, Indonesia.

San Juan, E. (2006). Toward a decolonizing indigenous psychology in the Philippines: Introducing Sikolohiyang Pilipino. Retrieved June 13, 2018 from https://www.tandfonline.com/ doi/full/ $10.1080 / 14797580500422018$ ? src=recsys

Senate of the Republic of the Philippines. (2017). Senate bill no. sbn-1528: an act establishing the department of culture, appropriating funds therefor, and for other purposes.

Septiarini, D. (2016). Decolonizing Filipino colonial mentality. In N. Supriatna, B. Hetharion, M. Tapung, S. Bahri, \& Rusmawan (Eds.). Promoting Justice and equal world, Vol. 1. Universitas Pendidikan Indonesia, Bandung, West Java, Indonesia.

Serafico, N. M. A. (2017). Linking classrooms and communities through place and community-based education: An exploratory analysis of the K-12 social studies curriculum in the Philippines. A paper presented during the 2nd International Seminar on Social Studies and History Education on October 26, 2017 at UPI, Badung, West Java, Indonesia.

Serrano, E., \& Paez, A. (2015). Principles of teaching 1. Quezon City: ADRIANA Publishing Co., Inc.

Smith, A. (1776). In Blenman, J. (2016). Adam Smith and "The wealth of nations". Retrieved June 18, 2018 from https://www.investopedia.com/updates/adamsmith-wealth-of-nations/

Sta. Ana, M. (2013). A curious case study on skin whitening and Filipinos: A fad or a sign of a confused, insecure identity? Retrieved, 28 December 2017, from http:// whatmichaellikes.blogspot.com/2013/10/filipinoand-colonial-mentality. html
Sta. Maria, M. (1996). Is the indigenization crisis in Philippine Social Sciences resolved in Sikolohiyang Pilipino? Layag, 1(1). Retrieved June 13, 2018 from https://ejournals.ph/article.php?id=1483

Supriatna, N. (2017). Ecopedagogy in social studies and history learning. In N. Supriatna, A. Sofyan, M. Somantri, R. T. Pratiwi, \& N. T. Sakung (Eds.). Empowering and engaging 21st century learner through social studies education, 2. Universitas Pendidikan Indonesia, Bandung, West Java, Indonesia.

Tarroja, M.C.H. (2010). Revisiting the definition and concept of Filipino family: A psychological perspective. Philippine Journal of Psychology, 43(2), 177-193.

Tiberius \& Tipping (1990). Twelve principles of effective teaching and learning: Teaching assistant handbook. Canada: University of Toronto.

Torres, R. (2007). Is decolonization necessary to the lives of Filipino people? Bulatlat, 7(26), 1-2.

Trendingtopmost.com. (2017). Top 10 coconut producing countries in the world. Retrieved January 01, 2018 from http://www.trendingtopmost.com/worldspopular-list-top-10/2017-2018-2019-2020-2021/ world/coconut-producing-countries-worldhighest-largest/

Villar, M. (2017). On service to the country. Retrieved June 13, 2018 from https://news.mb.com.ph/ 2017/01/10/on-service-to-the-country/

Vontz, T. (2000). We project citizens. Washington: USAID.

Walker, A. (1983). If the present looks like the past, what does the future look like? In Search of Our Mothers' Gardens, 290, 290-91. 